\title{
The flavivirus NS5 protein is a true RNA guanylyltransferase that catalyzes a two-step reaction to form the RNA cap structure
}

\author{
MOHESHWARNATH ISSUR, ${ }^{1,4}$ BRIAN J. GEISS, ${ }^{2,3,4}$ ISABELLE BOUGIE, ${ }^{1}$ FRÉDÉRIC PICARD-JEAN, ${ }^{1}$ \\ SIMON DESPINS, ${ }^{1}$ JOANNIE MAYETTE, ${ }^{1}$ SARAH E. HOBDEY, ${ }^{3}$ and MARTIN BISAILLON ${ }^{1}$ \\ ${ }^{1}$ Département de Biochimie, Faculté de Médecine, Université de Sherbrooke, Sherbrooke, Québec J1H 5N4, Canada \\ ${ }^{2}$ Department of Microbiology, Immunology, and Pathology, Colorado State University, Fort Collins, Colorado 80523, USA \\ ${ }^{3}$ Department of Biochemistry and Molecular Biology, Colorado State University, Fort Collins, Colorado 80523, USA
}

\begin{abstract}
The $5^{\prime}$-end of the flavivirus genome harbors a methylated ${ }^{\mathrm{m} 7} \mathrm{GpppA}_{2^{\prime} \mathrm{OMe}}$ cap structure, which is generated by the virus-encoded RNA triphosphatase, RNA (guanine-N7) methyltransferase, nucleoside 2'-O-methyltransferase, and RNA guanylyltransferase. The presence of the flavivirus guanylyltransferase activity in NS5 has been suggested by several groups but has not been empirically proven. Here we provide evidence that the N-terminus of the flavivirus NS5 protein is a true RNA guanylyltransferase. We demonstrate that GTP can be used as a substrate by the enzyme to form a covalent GMP-enzyme intermediate via a phosphoamide bond. Mutational studies also confirm the importance of a specific lysine residue in the GTP binding site for the enzymatic activity. We show that the GMP moiety can be transferred to the diphosphate end of an RNA transcript harboring an adenosine as the initiating residue. We also demonstrate that the flavivirus RNA triphosphatase (NS3 protein) stimulates the RNA guanylyltransferase activity of the NS5 protein. Finally, we show that both enzymes are sufficient and necessary to catalyze the de novo formation of a methylated RNA cap structure in vitro using a triphosphorylated RNA transcript. Our study provides biochemical evidence that flaviviruses encode a complete RNA capping machinery.
\end{abstract}

Keywords: flavivirus; RNA capping; RNA guanylyltransferase; RNA maturation

\section{INTRODUCTION}

The 5 '-end of eukaryotic mRNAs and many viral mRNAs harbors a ${ }^{\mathrm{m} 7} \mathrm{GpppN}$ cap structure that plays a crucial role in the translation and stability of mRNAs (Shuman 2000). Synthesis of the cap structure involves three distinct enzymatic activities (Furuichi and Shatkin 2000). In the first step of the reaction, the RNA 5 '-triphosphate end of the nascent RNA is hydrolyzed by an RNA triphosphatase (RTase) to form a diphosphate end. An RNA guanylyltransferase (GTase) then catalyzes a two-step reaction in which it utilizes GTP as a substrate to form a covalent GMP-enzyme intermediate. The GMP moiety is then transferred to the diphosphate end of the RNA transcript

\footnotetext{
${ }^{4}$ These authors contributed equally to this work.

Reprint requests to: Martin Bisaillon, Département de Biochimie, Faculté de Médecine, Université de Sherbrooke, 3001, 12e avenue, Sherbrooke, Québec J1H 5N5, Canada; e-mail: Martin.Bisaillon@USherbrooke.ca; fax: (819) 564-5340.

Article published online ahead of print. Article and publication date are at http://www.rnajournal.org/cgi/doi/10.1261/rna.1609709.
}

in the second step of the reaction to form the GpppN structure. Finally, the guanosine base is methylated by an RNA (guanine-N7) methyltransferase (N7MTase) to form the typical ${ }^{\mathrm{m} 7} \mathrm{GpppN}$ cap structure. The ribose of the nucleotides adjacent to the cap structure can also be $2^{\prime}$-O-methylated to various extents by a nucleoside $2^{\prime}-O$ methyltransferase (2'OMTase) (Shatkin 1976).

The Flavivirus genus includes more than 70 human pathogens such as West Nile, Yellow fever, and Dengue viruses (Heinz et al. 2000). The flavivirus genome is a single-stranded RNA of positive polarity that possesses a methylated cap 1 structure at its $5^{\prime}$ end $\left({ }^{\mathrm{m} 7} \mathrm{GpppA}_{2^{\prime} \mathrm{OMe}}{ }^{-}\right.$ RNA) (Brinton 2002). The genome encodes for a single open reading frame of $11 \mathrm{~kb}$ in length that is translated into a large polyprotein precursor, which is processed into three structural (capsid $\mathrm{C}$, membrane $\mathrm{M}$, and envelope $\mathrm{E}$ ) and seven nonstructural proteins (NS1, NS2A, NS2B, NS3, NS4A, NS4B, and NS5) by both viral and cellular proteases (Nowak et al. 1989; Wengler et al. 1991; Brinton 2002). The NS5 protein is the largest nonstructural protein of flaviviruses. It harbors the RNA-dependent RNA polymerase 
(RdRp) activity, which is required both for replication and transcription of the viral genome (Choi et al. 2004). The N-terminal domain of NS5 also contains N7MTase and 2'OMTase activities, both of which are involved in the synthesis of the RNA cap 1 structure (Egloff et al. 2002; Geiss et al. 2009). The RTase activity is mediated by the C-terminal domain of NS3 (Benarroch et al. 2004a), while the precise nature of the GTase remains uncertain. Recent cross-linking and fluorescence polarization assays have shown that GTP can bind to the MTase domain of NS5 with high affinity, and a thorough biochemical understanding of how the methyltransferase domain binds GTP is available (Bollati et al. 2009; Geiss et al. 2009). Crystal structures of the flavivirus MTase complexed with GTP show how the MTase can bind to GTP and suggest a possible site for GMP-enzyme formation (Egloff et al. 2002; Benarroch et al. 2004a; Assenberg et al. 2007; Egloff et al. 2007; Zhou et al. 2007; Bollati et al. 2009; Geiss et al. 2009). Moreover, the MTase domain of the NS5 protein of Wesselsbron virus was recently demonstrated to covalently bind GMP upon incubation with GTP, hinting to a possible role in RNA capping chemistry (Bollati et al. 2009). However, despite the structural and biochemical evidence suggesting that the NS5 MTase domain can bind GTP and form a GMPenzyme complex, there has been no experimental demonstration of GTase activity, i.e., there is no evidence that the GMP moiety can be transferred to an acceptor RNA.

In the present study we investigated if the flavivirus NS5 protein is a true RNA GTase, which can catalyze the formation of the viral RNA cap structure. We demonstrate that GTP can be used as a substrate by the flavivirus NS5 protein to form a covalent GMP-enzyme intermediate, and that the presence of NS3 is stimulatory to the formation of the GMP-enzyme intermediate. Furthermore, our data indicate that GMP can be transferred from NS5 to the diphosphate end of an acceptor RNA transcript. Finally, we show that NS3 and NS5 are sufficient for the formation of the complete RNA cap structure in vitro. These data demonstrate that the flavivirus NS5 protein is a true RNA GTase.

\section{RESULTS}

\section{Formation of an enzyme-GMP covalent intermediate}

The first step of the RNA GTase reaction entails the nucleophilic attack of the $\alpha$-phosphate of GTP by the enzyme and the subsequent formation of a covalent enzyme-GMP intermediate (Shuman and Hurwitz 1981; Shuman 1982; Venkatesan and Moss 1982). The ability of the purified fulllength NS5 $\left(\mathrm{NS}^{\mathrm{FL}}\right.$ ) protein (Fig. 1A) from West Nile virus (WNV) to form a covalent GMP-enzyme intermediate was detected by label transfer from $\left[\alpha-{ }^{32} \mathrm{P}\right] \mathrm{GTP}$ to the enzyme in the presence of magnesium ions. A single SDS-stable GMP-enzyme complex was detected following SDS-PAGE
(Fig. 1B). No labeling was observed upon incubation with $\left[\gamma-{ }^{32} \mathrm{P}\right]$ GTP (data not shown). Since the presence of pyrophosphate has been shown to strongly inhibit the forward RNA guanylyltransferase reaction (Ho et al. 1996), we therefore decided to investigate the effect of pyrophosphate on the reaction catalyzed by the WNV NS5 $5^{\mathrm{FL}}$ protein. Our results demonstrate that the addition of pyrophosphate inhibited the formation of the covalent enzyme-GMP intermediate. We therefore conclude that the WNV NS5 $5^{\mathrm{FL}}$ protein is active in the formation of a protein-GMP covalent complex, and that pyrophosphate is a potent inhibitor of the reaction.

The formation of the covalent $\mathrm{NS} 5^{\mathrm{FL}}-\mathrm{GMP}$ complex was quantified as described in Materials and Methods. As can be seen in Figure 1C, the yield of enzyme-GMP formation in the presence of $3 \mu \mathrm{M}(150 \mathrm{pmol})$ of $\mathrm{NS}^{\mathrm{FL}}$ increased as a function of GTP concentration. The titration assay indicated that half-saturation was reached at a concentration of $1 \mathrm{mM}$ GTP. At this GTP concentration, we estimated that at least $30 \%$ of the $\mathrm{NS}^{\mathrm{FL}}$ molecules were labeled with GMP in vitro (50 pmol of enzyme-GMP complex). As observed for other GTases (Cong and Shuman 1995; Ho et al. 1998a), this substoichiometric GMP labeling is likely due to the fact that a significant fraction of the enzyme is already guanylylated and remains so during purification of the enzyme from bacteria. Moreover, GTase activity was only observed in the presence of magnesium ions. Manganese, cobalt, calcium, copper, nickel, and zinc could not support the formation of the $\mathrm{NS}^{\mathrm{FL}}-\mathrm{GMP}$ complex (Fig. 1D).

In order to determine the nature of the enzyme-GMP linkage, the radiolabeled $\mathrm{NS} 5^{\mathrm{FL}}-\mathrm{GMP}$ complex was isolated by gel filtration, and submitted to chemical treatment. In the classical GTase reaction, the nucleophilic attack on the $\alpha$-phosphate of GTP by the enzyme results in the formation of a covalent intermediate in which GMP is typically covalently linked via a phosphoamide bond to the attacking lysine residue of the enzyme (Shuman and Hurwitz 1981; Cong and Shuman 1993; Pena et al. 1993). The reaction products resulting from chemical treatments were analyzed by thin-layer chromatography (Fig. 1E). Our data indicate that the $\mathrm{NS}^{\mathrm{FL}}-\mathrm{GMP}$ intermediate was resistant to $\mathrm{NaOH}$ treatment, but treatments with $\mathrm{HCl}$ or $\mathrm{NH}_{2} \mathrm{OH}$ resulted in the release of GMP, which is indicative of a phosphoamide linkage.

\section{The NS5 N-terminal methyltransferase domain forms a covalent linkage with GMP}

The N-terminal MTase domain of NS5 has been shown to bind to GTP (Egloff et al. 2002; Bollati et al. 2009; Geiss et al. 2009), and recent evidence suggests that an enzymeGMP complex can be formed within this domain of the Wesselsbron virus NS5 protein (Bollati et al. 2009). We wanted to validate to results from this paper and see if the 
A

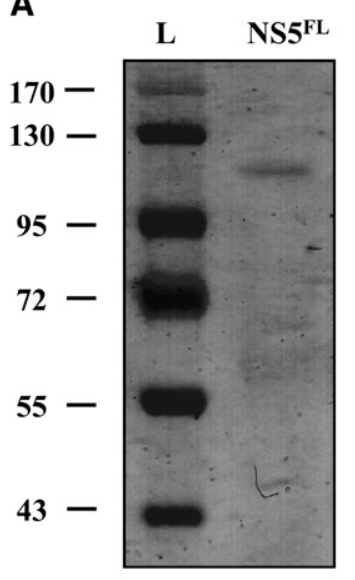

B

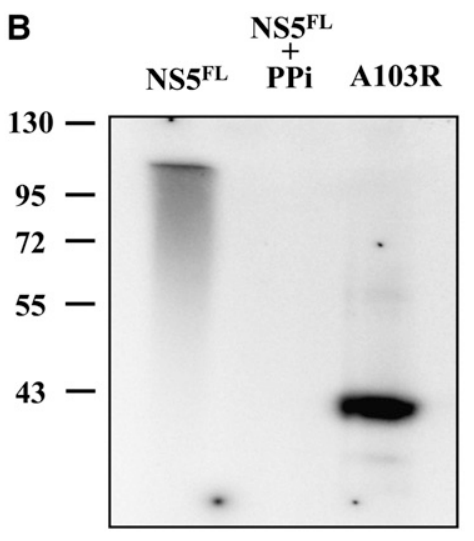

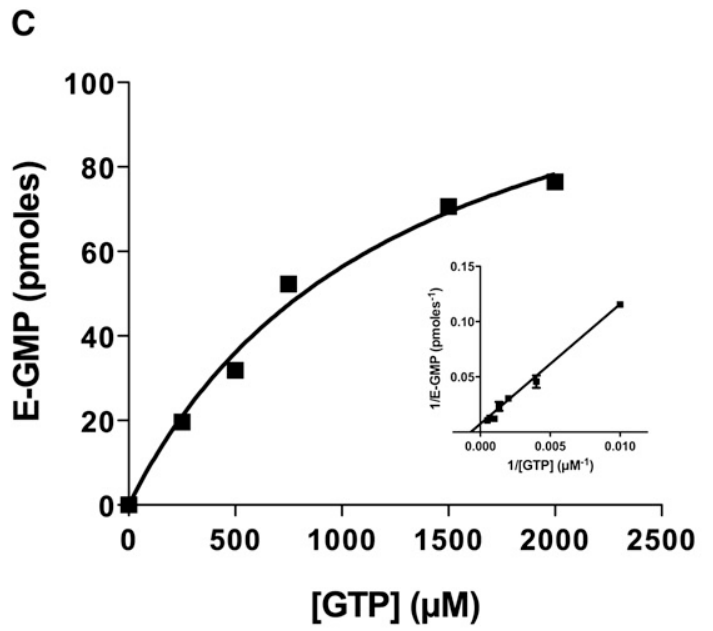

$\mathbf{E}$

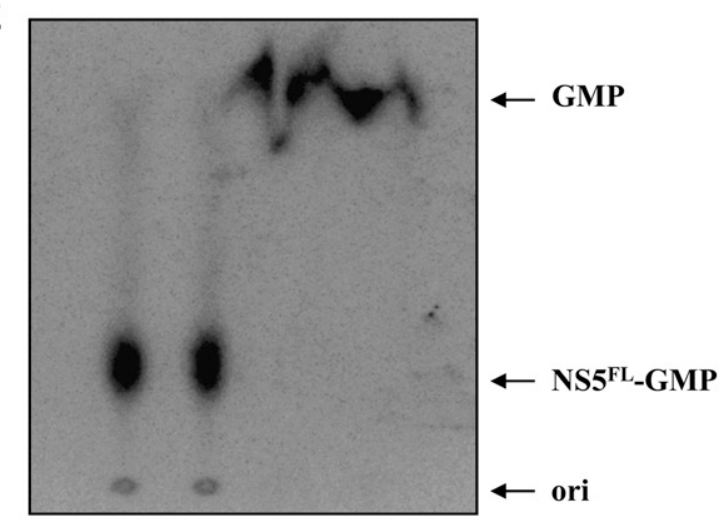

EpG NaOH $\mathrm{HCl} \mathrm{NH}_{2} \mathrm{OH}$

FIGURE 1. Formation of a NS5-GMP covalent intermediate. (A) An aliquot $(1 \mu \mathrm{g})$ of the purified full-length NS5 (NS5 $\left.{ }^{\mathrm{FL}}\right)$ protein from WNV was analyzed by electrophoresis through a $12.5 \%$ polyacrylamide gel containing $0.1 \%$ SDS and visualized by staining with Coomassie blue dye. The positions and sizes (in $\mathrm{kDa}$ ) of the molecular weight markers $(L)$ are indicated on the left. (B) Formation of an enzyme-GMP covalent intermediate. The $\mathrm{NS}^{\mathrm{FL}}$ enzyme $(3 \mu \mathrm{M})$ was incubated for $60 \mathrm{~min}$ at $37^{\circ} \mathrm{C}$ with $1 \mathrm{mM}\left[\alpha^{-}{ }^{32} \mathrm{P}\right] \mathrm{GTP}$ in a buffer containing $50 \mathrm{mM} \mathrm{Tris-HCl}$ at $\mathrm{pH}$ 7.5, $5 \mathrm{mM} \mathrm{DTT}$, and $5 \mathrm{mM} \mathrm{MgCl}_{2}$. Potassium pyrophosphate (PPi) $(1 \mathrm{mM})$ was also added to the reaction where indicated. A control reaction was also performed with $1 \mu \mathrm{g}$ of the RNA GTase from Paramecium bursaria Chlorella virus-1 (A103R). The reactions were stopped by the addition of EDTA to $10 \mathrm{mM}$ and SDS to $1 \%$, and analyzed by electrophoresis through a $12.5 \%$ polyacrylamide gel containing $0.1 \%$ SDS. An autoradiogram of the gel is shown. The positions and sizes (in $\mathrm{kDa}$ ) of the molecular weight markers are indicated on the left. (C) The extent of $\mathrm{NS} 5^{\mathrm{FL}}$-GMP complex formation is plotted as a function of GTP concentration. A double-reciprocal plot of the data is shown in the inset. $(D)$ Divalent cation specificity. Formation of the $\mathrm{NS}^{\mathrm{FL}}{ }^{-\mathrm{GMP}}$ complex was performed in the presence of $5 \mathrm{mM}$ divalent cation as specified. $\mathrm{Mg}$, Mn, $\mathrm{Co}, \mathrm{Ca}$, and $\mathrm{Zn}$ were added as chloride salts; $\mathrm{Cu}$ and $\mathrm{Ni}$ were added as sulfates. (E) The NS5 ${ }^{\mathrm{FL}}$-GMP labeled complex (EpG) was isolated by gel filtration and treated with either $0.5 \mathrm{M} \mathrm{NaOH}$ or $0.5 \mathrm{M} \mathrm{HCL}$ at $70^{\circ} \mathrm{C}$ for 10 min or with $3.8 \mathrm{M}$ hydroxylamine $\left(\mathrm{NH}_{2} \mathrm{OH}\right)$ in $0.2 \mathrm{M}$ sodium acetate $(\mathrm{pH} 4.8)$ at $37^{\circ} \mathrm{C}$ for $20 \mathrm{~min}$. The sample products were analyzed by thin-layer chromatography on a polyethyleneimine-cellulose plate and developed with $0.75 \mathrm{M} \mathrm{KH}_{2} \mathrm{PO}_{4}$. An autoradiogram of the plate is shown. The positions of the chromatographic origin (ori), the nucleotidylenzyme complex, and unlabeled GMP marker, visualized under ultraviolet light, are indicated.

enzyme-GMP complex can be formed by other flavivirus MTase domains. Incubation of the WNV NS5 MTase domain (amino acids 1-268) in the GTase reaction resulted in the transfer of a GMP moiety to the protein, indicating that the GMP-enzyme bond is formed within the first 268 amino acids of the NS5 protein (Fig. 2A). Note that the extent of NS5 $5^{1-268}$-GMP formation $(55 \mathrm{pmol} / 150 \mathrm{pmol}$ of enzyme) was comparable to the one observed for the fulllength protein. In order to evaluate whether this activity was common to other flaviviruses, we next tested the ability of other flavivirus NS5 proteins to form a protein-GMP covalent complex. Truncated versions of the NS5 protein from Dengue virus (DV) and Yellow fever virus (YFV) were incubated with radiolabeled GTP, and the formation of the enzyme-GMP covalent complex was evaluated by monitoring the transfer of radiolabeled GMP from $\left[\alpha-{ }^{32} \mathrm{P}\right] \mathrm{GTP}$ to the enzyme. Again, the formation of SDS-stable GMPenzyme complexes was detected following SDS-PAGE for 
A
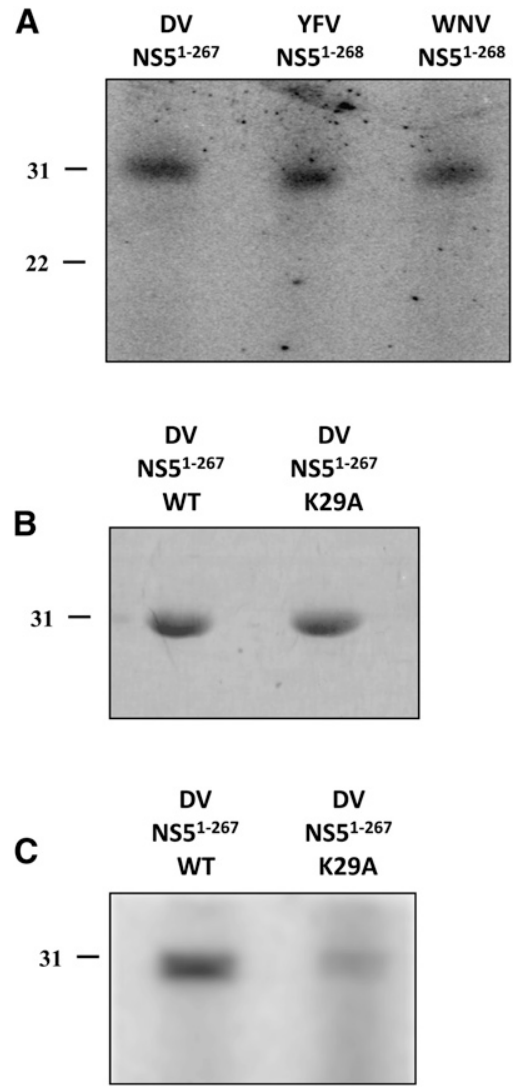

FIGURE 2. The NS5 N-terminal methyltransferase domain is active in the formation of a protein-GMP covalent complex. (A) The N-terminal MTase domain of the NS5 proteins $(3 \mu \mathrm{M})$ of Dengue virus (DV; strain 16681, amino acids 1-267), Yellow fever virus (YFV; strain 17D, amino acids 1-268), and West Nile virus (WNV; strain NY99, amino acids $1-268$ ) were incubated for $60 \mathrm{~min}$ at $37^{\circ} \mathrm{C}$ with 1 $\mathrm{mM}\left[\alpha-{ }^{32} \mathrm{P}\right] \mathrm{GTP}$ in a buffer containing $50 \mathrm{mM}$ Tris- $\mathrm{HCl}$ at $\mathrm{pH} 7.5$, $5 \mathrm{mM}$ DTT, and $5 \mathrm{mM} \mathrm{MgCl}$. The reactions were stopped by the addition of EDTA to $10 \mathrm{mM}$ and SDS to $1 \%$, and analyzed by electrophoresis through a $12.5 \%$ polyacrylamide gel containing $0.1 \%$ SDS. An autoradiogram of the gel is shown. The positions and sizes (in $\mathrm{kDa}$ ) of the molecular weight markers are indicated on the left. $(B)$ Mutational analysis of the N-terminal domain of the Dengue virus NS5 protein. Lys 29 was substituted for alanine in the DV (amino acids 1-267) construct, and the mutant polypeptide was expressed and purified in parallel with the corresponding wild-type enzyme. Aliquots $(3 \mu \mathrm{M})$ of the purified fractions were analyzed by electrophoresis through a $12.5 \%$ polyacrylamide gel containing $0.1 \%$ SDS and visualized by staining with Coomassie blue dye. The positions and sizes $(\mathrm{kDa})$ of the molecular weight markers are indicated on the left. (C) Effect of the K29A mutation on the formation of the covalent enzyme-GMP complex formation. The reactions were performed with $3 \mu \mathrm{M}$ of the mutant and wild-type proteins, and analyzed as described in $A$. The positions and sizes $(\mathrm{kDa})$ of the molecular weight markers are indicated on the left of the autoradiogram.

both enzymes (Fig. 2A). We hereby conclude that the formation of a GMP-enzyme complex is an intrinsic property of the N-terminal portion of the flavivirus NS5 protein.

A recent paper by Bollati et al. (2009) suggested that the GMP-enzyme bond is formed at Lys-29. However, the mass spectroscopy data reported in that paper appear to be in error, as the fragment reported as the GMP-modified peptide was the same size $(2225.12 \mathrm{MHz})$ as a commonly observed methylated trypsin fragment (Ding et al. 2003). Moreover, we were not able to detect a guanylylated K29 peptide by mass spectroscopy when the enzyme was incubated with GTP (data not shown). In order to shed light into the specific residues involved in the formation of the enzyme-GMP complex, a mutational analysis was performed on the DV NS5 protein. The Lys29 residue, which interacts with the $\alpha$-phosphate of GTP (Egloff et al. 2002; Geiss et al. 2009), was therefore substituted for alanine, and the mutant polypeptide was expressed and purified in parallel with the wild-type enzyme (Fig. 2B). The effect of this single alanine mutation on the formation of the covalent enzyme-GMP complex was then investigated. Alanine substitution of Lys29 resulted in a significant decrease in the ability of the enzyme to covalently bind GMP (Fig. 2C). The extent of NS5 ${ }^{\mathrm{K} 29 \mathrm{~A}}-\mathrm{GMP}$ formation at $1 \mathrm{mM}$ GTP (8 pmol of enzyme-GMP/3 $\mu \mathrm{M}$ of enzyme) was about $15 \%$ of the wild-type enzyme. We conclude that the residue is important for catalysis. However, the fact that a residual activity is still present raises speculations on its precise role in the reaction chemistry (see Discussion).

\section{NS5 is a true RNA guanylyltransferase}

RNA GTases catalyze a two-step reaction in which they initially form a covalent enzyme-GMP intermediate, which is transferred to an acceptor RNA molecule in the second part of the reaction. The flavivirus NS5 protein clearly has the ability to form a covalent GMP-enzyme intermediate, but can it transfer GMP to an RNA substrate containing a $5^{\prime}$-diphosphate end? We initially attempted to monitor the transfer of GMP to an acceptor RNA harboring a $5^{\prime}$-diphosphate end. This substrate was initially synthesized by in vitro transcription before being subjected to phosphohydrolysis in order to specifically remove the $\gamma$-phosphate. This RNA transcript harbors a guanosine as the initiating residue and is typically used in biochemical assays to monitor the transfer of the GMP moiety to an acceptor RNA. The ability of the enzyme to transfer GMP to this RNA molecule was tested by incubating the WNV NS5 ${ }^{\mathrm{FL}}$ protein with $\left[\alpha_{-}{ }^{32} \mathrm{P}\right] \mathrm{GTP}$, the RNA substrate (81 nucleotides [nt]) containing a diphosphate $5^{\prime}$-end, and magnesium ions. The products of the reaction were extracted with phenol/chloroform to remove the radiolabeled protein, and the RNA recovered by ethanol precipitation. However, following electrophoresis on a denaturing polyacrylamide gel (Fig. 3), we were unable to detect an efficient transfer of the GMP moiety from the flavivirus $\mathrm{NS}^{\mathrm{FL}}-\mathrm{GMP}$ complex to this acceptor RNA $(<0.05 \mathrm{pmol}$ of GMP transferred/7 pmol of $\mathrm{NS}^{\mathrm{FL}}$ ). Since the initiating residue of the flavivirus mRNAs is always an adenosine, we surmise that the nature of this residue might influence the RNA guanylyltransferase reaction. We therefore synthesized an RNA substrate harboring a $5^{\prime}$-diphosphate end with an adenosine as the 
initiating nucleotide (see Materials and Methods). The transfer of radiolabeled GMP to the RNA substrate was confirmed by electrophoresis on a denaturing polyacrylamide gel, indicating that the $\mathrm{NS} 5^{\mathrm{FL}}$ protein has the ability to transfer the GMP moiety to an acceptor RNA substrate harboring an adenosine as the initiating residue (Fig. 3). We evaluated that $5 \mathrm{pmol}$ of GMP were transferred to the RNA substrate in the presence of $7 \mathrm{pmol}$ of protein. We conclude that the NS5 protein is a true RNA GTase that catalyzes both steps of the typical RNA capping reaction.

\section{The NS3 protein stimulates the RNA guanylyltransferase activity}

Allosteric regulation frequently plays a crucial role in enzymatic catalysis. We therefore investigated the ability of various effectors to modulate the GTase activity of the WNV NS5 protein. The addition of $S$-adenosyl-L-methionine (AdoMet), which serves as the methyl donor during the MTase reaction, did not affect the formation of the enzyme-GMP intermediate (data not shown). Similarly, the addition of other nucleotides did not result in the stimulation of the activity (data not shown). The NS5 flexible linker region between the MTase and RdRp domains has been shown to be a site of interaction between the NS3 and NS5 proteins (Yon et al. 2005). As NS3 encodes the RTase enzyme, it seemed likely that the formation of the RNA cap structure is dependent on the interaction between these two proteins. To determine if NS3 can alter the GTase activity, we performed the GTase assay with the full-length WNV NS5 protein at a concentration $2 \mu \mathrm{M}$ in the presence of the WNV NS3 ${ }^{168-618}$ protein $(10 \mu \mathrm{M})$. We observed that the addition of the purified WNV NS3 protein, which has no GTase activity of its own, significantly increased the formation of the $\mathrm{NS}^{\mathrm{FL}}$ GMP complex (Fig. 4A). The activity increased from 15 pmol of $\mathrm{NS}^{\mathrm{FL}}$-GMP complex/100 pmol of $\mathrm{NS}^{\mathrm{FL}}$ to 45 pmol of $\mathrm{NS}^{\mathrm{FL}}-\mathrm{GMP} / 100$ pmol of $\mathrm{NS}^{\mathrm{FL}}$ when the assay was performed in the presence of NS3 ${ }^{168-618}$. Moreover, we observed that the extent of $\mathrm{NS}^{\mathrm{FL}}{ }^{\mathrm{L}}-\mathrm{GMP}$ complex formation was proportional to the concentration of input NS3 in the 4-20 $\mu \mathrm{M}$ and plateaued thereafter (Fig. 4B). A maximal stimulation of sixfold was reached at a $\sim 6: 1$ molar ratio of NS3 to NS5.

\section{Synthesis of the RNA cap structure by the NS3 and NS5 proteins}

We finally tested the ability of the flavivirus NS3 and NS5 proteins to catalyze the de novo formation of a methylated
RNA cap structure. An 81 nt RNA substrate harboring a $5^{\prime}$-triphosphate end with an adenosine as the initiating nucleotide was incubated with the WNV NS3 protein (RTase). The resulting RNA product was then incubated with the WNV NS5 ${ }^{\mathrm{FL}}$ protein and $\left[\alpha-{ }^{32} \mathrm{P}\right] \mathrm{GTP}$ in the presence or absence of $S$-adenosyl-methionine. The products of the reaction were extracted with phenol/chloroform to remove the radiolabeled protein, and the RNA products were recovered by ethanol precipitation. The transfer of the radiolabeled GMP to the RNA substrate was confirmed by electrophoresis on a denaturing polyacrylamide gel, thereby indicating that the NS5 protein has the ability to transfer a GMP moiety to the $5^{\prime}$-diphosphate end of an acceptor RNA substrate that was generated through the RNA $5^{\prime}$-triphosphatase activity of NS3 (Fig. 5A). Note that the transfer of the radiolabeled GMP moiety to the RNA was not observed in control reactions performed in the absence of either NS3 or $\mathrm{NS}^{\mathrm{FL}}$ (Fig. 5A). Aliquots of the RNA samples were then digested with nuclease P1 and alkaline phosphatase, and analyzed by polyethyleneimine-cellulose thin-layer chromatography (Fig. 5B). The reaction performed in the presence of $S$-adenosyl-methionine displayed a faster migrating species corresponding to the RNA cap ${ }^{\mathrm{m} 7} \mathrm{GpppA}$ structure, as judged from the unlabeled markers, visualized under ultraviolet light. These data indicate that NS3 and NS5 are the sole flaviviral enzymes involved in genomic RNA cap formation, and that we have observed the formation of a flavivirus RNA cap structure in vitro.

\section{DISCUSSION}

Our study provides biochemical evidences that the flavivirus NS5 protein is a true RNA GTase that has the ability to form a covalent protein-GMP intermediate and subsequently transfer the GMP moiety to a 5'-diphosphate RNA. 
A

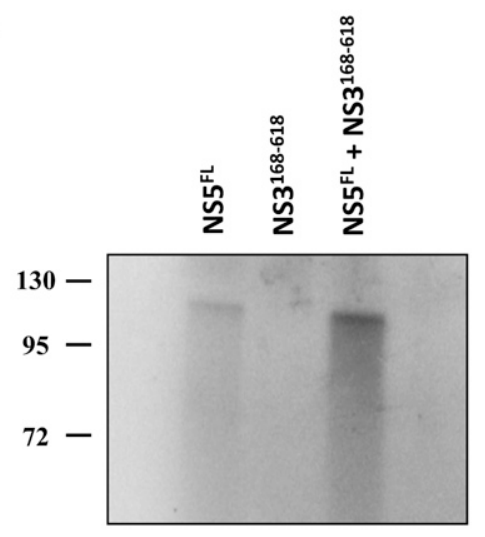

B

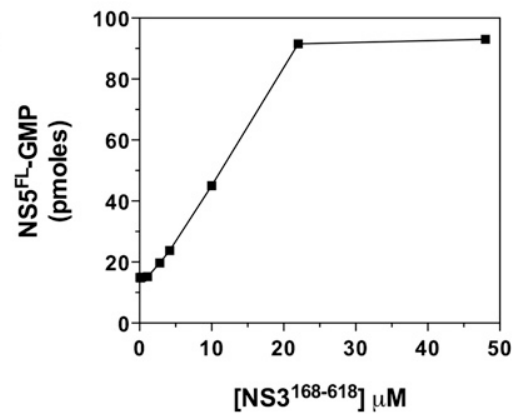

FIGURE 4. Stimulation of the GTase activity by the NS3 protein. $(A)$ The WNV NS5 ${ }^{\mathrm{FL}}$ protein $(2 \mu \mathrm{M})$ was incubated in the absence or presence of purified WNV NS3 $3^{168-618}$ protein $(10 \mu \mathrm{M})$ for $60 \mathrm{~min}$ at $37^{\circ} \mathrm{C}$ with $1 \mathrm{mM}\left[\alpha-{ }^{32} \mathrm{P}\right] \mathrm{GTP}$ in a buffer containing $50 \mathrm{mM}$ Tris- $\mathrm{HCl}$ at $\mathrm{pH} 7.5,5 \mathrm{mM}$ DTT, and $5 \mathrm{mM} \mathrm{MgCl}$. As a control, the purified NS3 ${ }^{168-618}$ protein was also assayed in the absence of $\mathrm{NS}^{\mathrm{FL}}$. The reactions were stopped by the addition of EDTA to $10 \mathrm{mM}$ and SDS to $1 \%$, and analyzed by electrophoresis through a $12.5 \%$ polyacrylamide gel containing $0.1 \%$ SDS. An autoradiogram of the gel is shown. The positions and sizes $(\mathrm{kDa})$ of the molecular weight markers are indicated on the left. (B) Increasing concentrations of NS3 ${ }^{168-618}$ were used in the GTase assay, and the formation of the NS5 ${ }^{\mathrm{FL}}-\mathrm{GMP}$ complex was monitored through electrophoresis and autoradiography. The intensities of the NS5 ${ }^{\mathrm{FL}}$-GMP complexes were normalized to the signal obtained in the absence of NS3 $3^{168-618}$ protein.

There have been several pieces of evidence used to suggest that NS5 MTase domain contains the flaviviral GTase activity, including structural and biochemical analysis of MTase GTP binding, limited data showing covalent formation of a GMP-enzyme complex, and structural data with cap analogs to propose a mechanism for RNA capping (Egloff et al. 2002, 2007; Geiss et al. 2009). These reports, while important to understand the MTase activity of the enzyme, did not demonstrate that the MTase domain catalyzes a true GTase reaction. The data that we present in the current study fill this gap by demonstrating that NS5 can catalyze both steps of the RNA GTase reaction. Moreover, the enzyme can synthesize a complete methylated cap structure in the presence of NS3 using a nascent triphosphorylated RNA transcript harboring a $5^{\prime}$ adenine base. Therefore, we conclude that the N-terminus of NS5, in combination with the NS3 RTase, comprises the complete flavivirus capping enzyme.

The identification of the flaviviral RNA GTase highlights the large diversity in the physical organization of the RNA capping machineries. For instance, the RTase and GTase activities of metazoans and plants are catalyzed by a single protein, which contains both active sites, while both the N7MTase and 2'OMTase activities reside on separate singledomain enzymes (Shuman 2000). In yeast, the RTase, GTase, and N7MTase are all catalyzed by separate proteins (Shibagaki et al. 1992; Mao et al. 1995). Interestingly, an important variety of molecular organizations has been observed for viruses. For instance, the poxviruses harbor a single protein that contains the active site for the RTase, GTase, and N7MTase, while a different protein is responsible for the 2'OMTase activity (Higman et al. 1994; Schwer et al. 2006). In alphaviruses, both the GTase and N7MTase activities are catalyzed by a single enzyme while the RTase active site is located on a different peptide (Ahola and Kääriäinen 1995; Vasiljeva et al. 2000). Mammalian reoviruses harbor a single multifunctional protein containing the active sites of the GTase, N7MTase, and 2'OMTase, while the RTase reaction is performed by a distinct protein (Bisaillon and Lemay 1997a; Luongo et al. 2000). This particular RNA capping machinery is reminiscent of what is observed in flaviviruses, where the NS3 protein contains the active site of the RTase, while the NS5 protein is responsible for the N7MTase, 2'OMTase, and GTase activities. However, a distinction between the two viral families is the additional presence of the RNA polymerase active site on the multifunctional enzyme (NS5) (Oh et al. 1999). The multiple essential enzymatic activities catalyzed by the flavivirus NS5 protein clearly make it an attractive target for future drug development.

The GTases of metazoans, plants, and DNA viruses are members of the covalent nucleotidyl transferase superfamily, which also includes DNA and RNA ligases (Cong and Shuman 1993). These GTases harbor a consensus KxDG motif in which the $\varepsilon$-amino group of the active-site lysine is covalently bound to GMP through a phosphoamide bond (Cong and Shuman 1993). However, the GTases of several RNA viruses lack this precise consensus sequence found in DNA viruses and cellular GTases. For instance, this consensus signature is not found in the GTase of alphaviruses and several genera of the Reoviridae family (Cleveland et al. 1986; Le Blois et al. 1992; Liu et al. 1992; Ahola and Kääriäinen 1995; Suzuki et al. 1996; Bisaillon and Lemay 1997b; Hsiao et al. 2002; Qiu and Luongo 2003; Mohd Jaafar et al. 2005; Supyani et al. 2007). Similarly, the KxDG consensus sequence is conspicuously absent from the NS5 protein of flaviviruses. Henceforth, we speculate that the residue involved in the formation of the covalent enzymeGMP intermediate is either a lysine located outside the classically consensus sequence or mediated via a completely 
A

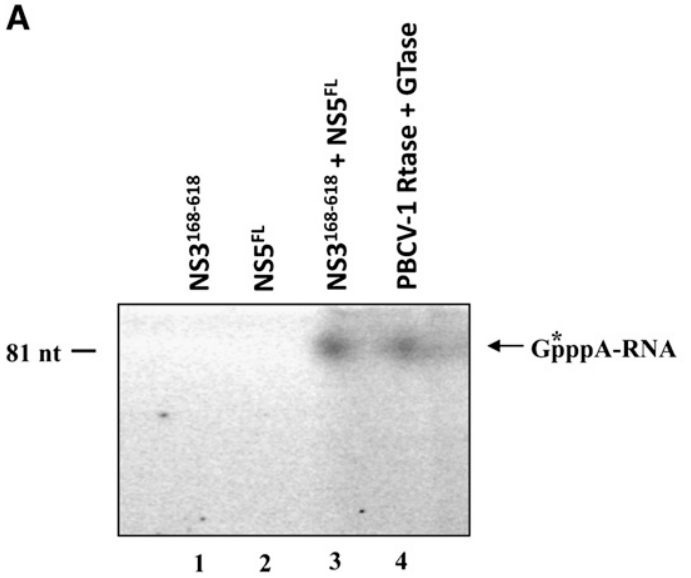

B

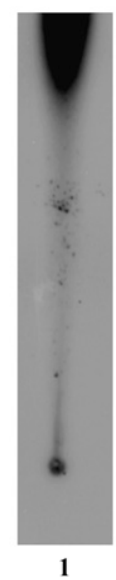

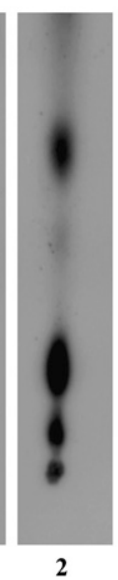

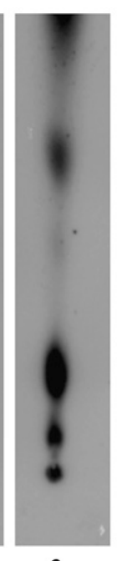

3
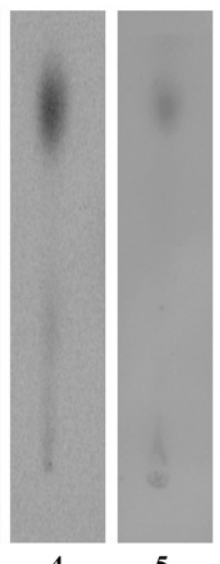

$\leftarrow \mathrm{Pi}$

$\leftarrow{ }^{\mathrm{m} 7} \mathrm{GpppA}$

$\leftarrow$ GppA

E-GMP

$\leftarrow$ Undigested RNA

$\leftarrow$ ori

FIGURE 5. Synthesis of the RNA cap 1 structure by the NS3 and NS5 proteins. (A) The RNA capping reaction was initiated by performing an RTase assay in a buffer containing $50 \mathrm{mM}$ Tris- $\mathrm{HCl}$ at pH 7.5, $5 \mathrm{mM}$ DTT, $20 \mathrm{pmol}$ of triphosphate-terminated RNA, and $2 \mu \mathrm{M}$ of purified WNV $\mathrm{NS} 3^{168-618}$ protein. The reaction was incubated at $37^{\circ} \mathrm{C}$ for $60 \mathrm{~min}$. The RNA was extracted with phenol/chloroform, recovered by ethanol precipitation, adjusted to $5 \mathrm{mM} \mathrm{MgCl}$, and the GTase reaction was performed in the presence of $3 \mu \mathrm{M}$ of purified WNV NS5 $5^{\mathrm{FL}}$ protein and $1 \mathrm{mM}\left[\alpha-{ }^{32} \mathrm{P}\right]$ GTP. The sample was incubated at $37^{\circ} \mathrm{C}$ for $60 \mathrm{~min}$. The RNA sample was extracted with phenol/chloroform, recovered by ethanol precipitation, and analyzed on a denaturing $10 \%$ polyacrylamide gel (lane 3). An autoradiogram of the polyacrylamide gel is shown. A control reaction was also performed with the RTase (A449R) and GTase (A103R) of Paramecium bursaria Chlorella virus (PBCV-1) (lane 4). Control reactions were also performed in the presence of WNV NS3 ${ }^{168-618}$ (lane 1) or NS5 ${ }^{\mathrm{FL}}$ proteins (lane 2). The position of the radiolabeled phosphate, originating from the $\left[\alpha-{ }^{32} \mathrm{P}\right] \mathrm{GTP}$ substrate, is denoted by an asterisk. (B) Aliquots of the RNA capping reactions were adjusted to $50 \mathrm{mM} \mathrm{NaOAc}$ at $\mathrm{pH} 5.2$, and digested with nuclease $\mathrm{P} 1(5 \mu \mathrm{g})$ for $60 \mathrm{~min}$ at $37^{\circ} \mathrm{C}$. The reactions were then adjusted to $50 \mathrm{mM} \mathrm{Tris-} \mathrm{HCl}$ at $\mathrm{pH} 8.0$, and digested with alkaline phosphatase (1 unit) for $30 \mathrm{~min}$ at $37^{\circ} \mathrm{C}$. The reaction products were analyzed by thin-layer chromatography on a polyethyleneimine-cellulose plate developed with $0.5 \mathrm{M} \mathrm{LiCl} / 1 \mathrm{M}$ formic acid. An autoradiogram of the plate is shown. (Lane 1) Control reaction performed in the absence of protein. (Lane 2) Control reaction performed with the Chlorella virus GTase (A103R). (Lane 3) Reaction performed with the WNV NS5 ${ }^{\mathrm{FL}}$ protein. (Lane 4) The RNA from the standard GTase reaction (performed with A103R) was extracted with phenol/ chloroform and recovered by ethanol precipitation. The purified RNA was then subjected to a standard MTase reaction with the S. cerevisiae MTase (Abd1) in the presence of $1 \mathrm{mM}$ S-adenosyl-methionine. (Lane 5) The RNA from the GTase reaction performed with the WNV NS5 ${ }^{\mathrm{FL}}$ protein was extracted with phenol/chloroform and recovered by ethanol precipitation. The purified RNA was then subjected to a methylation reaction with the $\mathrm{NS}^{\mathrm{FL}}$ in the presence of $1 \mathrm{mM} \mathrm{S}$-adenosyl-methionine; The positions of the chromatographic origin (ori), GpppA, and ${ }^{\mathrm{m} 7} \mathrm{GpppA}$ are indicated.

different amino acid residue, since formation of the enzyme-GMP intermediate can potentially occur with the imidamino group of a histidine residue and the guanidoamino group of an arginine residue (Shuman and Hurwitz 1981). Mutagenesis studies of the DV NS5 protein by us and others have highlighted the importance of Lys29 in the binding of GTP (Bollati et al. 2009; Geiss et al. 2009). However, a residual GTase activity is still present upon substitution of the lysine residue by alanine, which raises questions about the precise role of the lysine residue in the catalytic activity. Interestingly, the residue next to the Lys 29 residue is also a lysine (Lys-30) in the DV NS5 protein. It is possible that altering the structure of the protein upon replacement of the Lys 29 residue by alanine may allow the Lys30 residue to come closer than it normally would and form a weak bond with the GMP moiety. Surprisingly, the Lys 29 position is not strictly occupied by a lysine residue in all flaviviruses; in some members of the family, such as West Nile virus, Japanese encephalitis, and St. Louis encephalitis virus, an arginine is found at the position normally occupied by the lysine (Bollati et al. 2009). This is somewhat surprising since all known GTases identified so far are thought to bind the GMP moiety through a lysine residue
(Shuman and Hurwitz 1981; Cong and Shuman 1993; Pena et al. 1993). The precise biochemical consequences of this conservative substitution remain to be investigated.

The crystal structures of different members of the nucleotidyl transferase superfamily have been determined and have provided insightful information on the GTase reaction chemistry (Doherty et al. 1997; Hakansson et al. 1997; Lee et al. 2000; Odell et al. 2000; Fabrega et al. 2003). Members of the family are characterized by a common tertiary fold that consists of an N-terminus, which encompasses the nucleotide-binding pocket, and a C-terminal oligonucleotide binding-fold domain (Hakansson and Wigley 1998; Odell et al. 2000; Benarroch et al. 2004b; Yap et al. 2007; Malet et al. 2007). Examination of the Chlorella virus GTase crystals have revealed that a large conformational change occurs on GTP binding, shifting the structure from an open to a closed state (Hakansson et al. 1997; Hakansson and Wigley 1998). On the basis of these crystallographic studies, a model has been suggested, in which the conformational change encountered on GTP binding would promote metal ion binding and guanylylation (Hakansson et al. 1997; Hakansson and Wigley 1998). In contrast, recent crystallographic data suggest the presence 
of important structural and mechanistic differences between the flavivirus NS5 protein and the members of the nucleotidyl transferase superfamily (Hakansson and Wigley 1998; Ago et al. 1999; Bressanelli et al. 1999; Lesburg et al. 1999; Benarroch et al. 2004b; Malet et al. 2007; Yap et al. 2007). The GTase-MTase domain of the flavivirus NS5 protein is characterized by three subdomains with a core region that resembles the topology observed in the catalytic domain of all other AdoMet-dependent MTases (Lesburg et al. 1999; Bollati et al. 2009; Geiss et al. 2009;). The GTPbinding site located on the $\mathrm{N}$-terminal appendage of the classical MTase core region shows a previously unreported fold and a structurally novel way of promoting the specific binding of GTP by which the specific contacts to the guanine base are exclusively provided by main-chain atoms to the 2-amino group and the $\mathrm{N} 1$ nitrogen via a water bridge (Geiss et al. 2009). This is in contrast to the nucleotidyl transferase superfamily GTases in which the specificity for GTP is achieved through interactions with the 6-oxo and 2-amino group of guanine (Doherty et al. 1997; Hakansson et al. 1997; Lee et al. 2000; Odell et al. 2000; Fabrega et al. 2003). Finally, binding of the GTP molecule to the flavivirus GTase active site is not characterized by large conformational changes in the architecture of the enzyme (Geiss et al. 2009).

Our study demonstrates that the GTase activity of NS5 is stimulated by the presence of NS3. Future biochemical studies will undoubtedly reveal key insights on this catalytic regulation. Interestingly, a similar stimulation of the GTase (Ceg1) upon binding to the RTase (Cet1) is also observed in Saccharomyces cerevisiae, where the Cet1-Ceg1 interaction increases the extent of formation of the Ceg1-GMP complex (Ho et al. 1998a, 1999; Hausmann et al. 2001). This interaction is crucial for the stabilization of the yeast GTase, which is inherently thermolabile (Hausmann et al. 2001). Moreover, the interaction also enhances the affinity of the enzyme for the GTP substrate (Ho et al. 1998b). Such an allosteric stimulation of an enzyme involved in RNA capping chemistry is also encountered in the vaccinia virus capping machinery, where the active site of the N7MTase is located within the C-terminal portion of the virus-encoded D1 protein (Schnierle et al. 1992; Mao and Shuman 1994). The D1 protein has a weak intrinsic MTase activity, which is stimulated allosterically by the binding of the viral D12 protein (Mao and Shuman 1994). The basal level of MTase activity can be stimulated by as much as 100 -fold by the addition of the catalytically inert D12 protein (Mao and Shuman 1994). NS3 is known to interact with the flexible linker region on NS5, positioning NS3 between the NS5 RdRP and MTase-GTase domains (Yon et al. 2005). With the current demonstration that NS3 can stimulate the NS5 GTase activity and that NS3 and NS5 are sufficient for RNA cap formation, a model of the entire RNA capping process can now be proposed (Fig. 6). In this model, the nascent positive strand RNA immediately interacts with the NS3
RTase following polymerization by the NS5 C-terminal $\mathrm{RdRp}$, leading to the removal of the $\gamma$-phosphate from the RNA. The modified RNA would then be in position to interact with the NS5 MTase-GTase domain. Association of NS3 with NS5 increases the GTase activity of the MTaseGTase domain, and results in the transfer of GMP to the modified RNA, resulting in the synthesis of a capped RNA transcript. Subsequently, the modified RNA would be in excellent position for N7-methylation to generate the RNA cap structure. Future studies will seek to rigorously test this model for RNA cap formation.

Because of the crucial role of the RNA cap structure for mRNA metabolism and stability, potent inhibitors of pathogen GTases are an attractive area for drug development. For instance, an elegant study recently demonstrated the ability of non-nucleoside inhibitors to inhibit the mRNA guanylylation of the human respiratory syncytial virus transcripts (Liuzzi et al. 2005). These GTase inhibitors were shown to exhibit antiviral activities both in vitro and in a mouse model of infection. The broad-spectrum antiviral ribavirin triphosphate, a nucleoside analog, has also been shown to directly interact with the guanylyltransferase of vaccinia virus, thereby inhibiting the guanylylation of RNA transcripts (Bougie and Bisaillon 2004). However, because of the high overall similarity between viral and cellular GTases, it was initially suggested that mechanism-based inhibitors might not be specific and show adverse side effects on human cells (Bougie and Bisaillon 2004). Nonetheless, mounting evidence suggests that subtle structural and mechanistic differences exist between the RNA viruses and cellular GTases. These differences will undoubtedly be exploited in the near future for the rational design of potent antivirals against these medically important viruses.

\section{MATERIALS AND METHODS}

\section{Expression and purification of the flavivirus NS5 protein}

Expression and purification of the NS5 and NS3 protein from West Nile virus, Dengue virus, and Yellow fever virus was performed as described previously (Benzaghou et al. 2006; Bougie and Bisaillon 2009; Geiss et al. 2009). Briefly, recombinant fulllength WNV NS5 protein (strain NY1999, amino acids 1-905), truncated WNV NS3 protein (strain NY99, amino acids 168-618), and the NS5 MTase domains from DV (strain 16681, amino acids 1-267), YFV (strain 17D, amino acids 1-268), and WNV (strain NY1999, amino acids 1-268) were expressed from inducible T7 expression plasmids that contain a carboxy-terminal 6-histidine tag. The plasmids were transformed into Escherichia coli BL21(DE3) and cultures were induced with $400 \mu \mathrm{M}$ IPTG overnight at $18^{\circ} \mathrm{C}$. The bacterial pellets were collected, sonicated, and the histidine-tagged proteins were purified from clarified lysates by affinity chromatography based on the affinity of the tag for immobilized nickel. The eluted proteins were further purified 


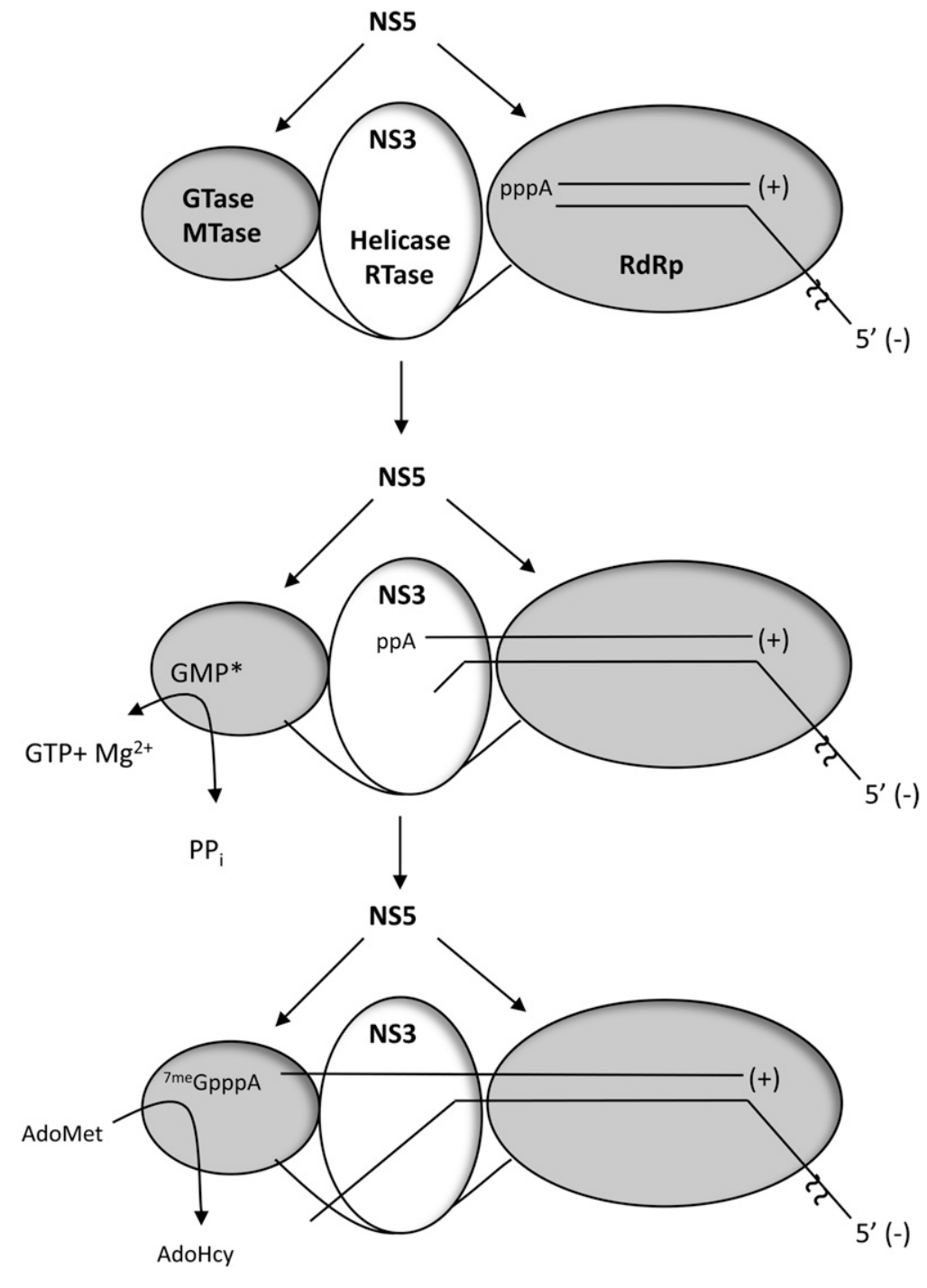

FIGURE 6. RNA cap synthesis by the flavivirus NS5 and NS3 proteins. The flavivirus NS5 protein harbors the catalytic center of the RNA-dependent RNA polymerase (RdRp) and initiates the synthesis of the triphosphorylated RNA transcript. The C-terminal region of NS3 is responsible for the helicase activity, which is necessary to allow progression of the polymerase along the template strand. The nascent RNA then interacts with the NS3 RTase leading to the removal of the $\alpha$-phosphate from the RNA. The modified RNA would then be in position to interact with the NS5 MTase-GTase domain. The interaction between NS3 and NS5 increases the GTase activity of the NS5 protein, generating a covalent intermediate $\left(\mathrm{EpG}^{*}\right)$ in which the GMP moiety is linked to NS5. Subsequently, the NS5 protein can catalyze the transfer of GMP to the acceptor RNA resulting in the synthesis of a capped RNA transcript. The capped RNA would then be methylated to generate the RNA cap structure.

over a HiTrap-S cation-exchange column (Amersham). The isolated proteins were $>99 \%$ pure as estimated from SDS-PAGE and Coomasie blue staining.

\section{Assay for enzyme-GMP complex formation}

The assay was performed by incubating the enzyme $(3 \mu \mathrm{M})$ with $1 \mathrm{mM}\left[\alpha_{-}{ }^{32} \mathrm{P}\right] \mathrm{GTP}$ in a buffer containing $50 \mathrm{mM}$ Tris- $\mathrm{HCl}$ at $\mathrm{pH}$ 7.5, $5 \mathrm{mM} \mathrm{DTT}$, and $5 \mathrm{mM} \mathrm{MgCl}_{2}$ for $60 \mathrm{~min}$ at $37^{\circ} \mathrm{C}$. The reactions were stopped by the addition of EDTA to $10 \mathrm{mM}$ and SDS to $1 \%$. The reactions were analyzed by electrophoresis through a $12.5 \%$ polyacrylamide gel containing $0.1 \%$ SDS. The radiolabeled proteins were visualized by autoradiography of the gel. The extent of covalent complex formation was quantitated by scanning the gel with a PhosphorImager (Amersham Biosciences).

Alternatively, the NS5-GMP labeled complex was isolated by gel filtration and treated with either $0.5 \mathrm{M} \mathrm{NaOH}$ or $0.5 \mathrm{M} \mathrm{HCL}$ at $70^{\circ} \mathrm{C}$ for $10 \mathrm{~min}$ or with $3.8 \mathrm{M}$ hydroxylamine $\left(\mathrm{NH}_{2} \mathrm{OH}\right)$ in $0.2 \mathrm{M}$ sodium acetate ( $\mathrm{pH} 4.8$ ) at $37^{\circ} \mathrm{C}$ for $20 \mathrm{~min}$. The sample products were analyzed by thin-layer chromatography on a polyethyleneimine-cellulose plate and developed with $0.75 \mathrm{M}$ $\mathrm{KH}_{2} \mathrm{PO}_{4}$.

\section{Preparation of the $5^{\prime}$-diphosphate RNA substrate}

An RNA substrate of $81 \mathrm{nt}$ was synthesized using a pair of complementary oligonucleotides including a modified T7 RNA promoter (TAATACGACTCACTATAAGC), which allowed the synthesis of an RNA transcript (pppAGCCATG...) that harbored an adenosine as the initiating nucleotide. A standard T7 RNA promoter was also used as a control to generate an RNA harboring a guanosine as the initiating nucleotide. The sequences of these RNAs are not derived from WNV and contain a random sequence having no bearing to the sequence or structure of the $5^{\prime}$ terminus of the WNV positive stranded RNA. In both cases, the RNA substrates of $81 \mathrm{nt}$ were synthesized with the MAXIscript kit (Ambion) using T7 RNA polymerase. The corresponding bands were excised and then eluted from the gel by an overnight incubation in $0.1 \%$ SDS and $0.5 \mathrm{M}$ ammonium acetate. The 5'-triphosphate RNAs were then precipitated with ethanol and quantified by spectrophotometry. An RNA triphosphatase reaction was performed in a buffer containing $50 \mathrm{mM}$ Tris/ $\mathrm{HCl}$ at $\mathrm{pH}$ 7.0, $5 \mathrm{mM}$ DTT, $1 \mathrm{mM} \mathrm{MgCl} 2,1 \mathrm{pmol}$ of RNA, and $1 \mu \mathrm{g}$ of purified Chlorella virus RTase. The reaction mixture was incubated at $30^{\circ} \mathrm{C}$ for $30 \mathrm{~min}$, and stopped by the addition of formic acid $(1.25 \mathrm{M})$. The RNA substrate was purified on a denaturing $20 \%$ polyacrylamide gel and visualized by ultraviolet shadowing. The corresponding band was excised and then eluted from the gel by an overnight incubation in $0.1 \%$ SDS and $0.5 \mathrm{M}$ ammonium acetate. The $5^{\prime}$-diphosphate RNA was then precipitated with ethanol and quantified by spectrophotometry.

\section{Transfer of GMP to RNA}

The transfer of GMP to the 5 '-diphosphate RNA was assayed by monitoring the transfer of $\left[{ }^{32} \mathrm{P}\right] \mathrm{GMP}$ to the RNA substrate $(1 \mu \mathrm{g})$ 
in a buffer containing $50 \mathrm{mM}$ Tris- $\mathrm{HCl}$ at $\mathrm{pH} 7.5,5 \mathrm{mM} \mathrm{MgCl}_{2}$, $5 \mathrm{mM}$ DTT, $2 \mu \mathrm{M}$ of purified $\mathrm{NS}^{\mathrm{FL}}$ protein, and $1 \mathrm{mM}$ $\left[\alpha-{ }^{32} \mathrm{P}\right] \mathrm{GTP}$. The reaction was incubated at $37^{\circ} \mathrm{C}$ for $60 \mathrm{~min}$, the RNA was extracted with phenol/chloroform and recovered by ethanol precipitation. The RNA was analyzed on a denaturing $10 \%$ polyacrylamide gel. The gel was then scanned with a PhosphorImager (Amersham Biosciences).

\section{Synthesis of the RNA cap structure by the WNV NS3 and NS5 proteins}

The RNA capping reaction was performed in a buffer containing $50 \mathrm{mM}$ Tris- $\mathrm{HCl}$ at $\mathrm{pH} 7.5,5 \mathrm{mM}$ DTT, $1 \mu \mathrm{g}$ of triphosphateterminated RNA ( $81 \mathrm{nt}$ ), and $2 \mu \mathrm{M}$ of purified WNV NS3 $3^{168-618}$ protein. The reaction was incubated at $37^{\circ} \mathrm{C}$ for $60 \mathrm{~min}$. The RNA was extracted with phenol/chloroform, recovered by ethanol precipitation, adjusted to $5 \mathrm{mM} \mathrm{MgCl}_{2}$, and incubated with $3 \mu \mathrm{M}$ of purified WNV NS5 ${ }^{\mathrm{FL}}$ protein and $1 \mathrm{mM}\left[\alpha-{ }^{32} \mathrm{P}\right] \mathrm{GTP}$. The sample was incubated at $37^{\circ} \mathrm{C}$ for $60 \mathrm{~min}$. The RNA sample was extracted with phenol/chloroform, recovered by ethanol precipitation, and analyzed on a denaturing $10 \%$ polyacrylamide gel .

Alternatively, aliquots of the RNA capping reactions were adjusted to $50 \mathrm{mM} \mathrm{NaOAc}$ at $\mathrm{pH} 5.2$, and digested with nuclease $\mathrm{P} 1(5 \mu \mathrm{g})$ for $60 \mathrm{~min}$ at $37^{\circ} \mathrm{C}$. The reactions were then adjusted to $50 \mathrm{mM}$ Tris- $\mathrm{HCl}$ at $\mathrm{pH} 8.0$, and digested with alkaline phosphatase ( 1 unit) for $30 \mathrm{~min}$ at $37^{\circ} \mathrm{C}$. The reaction products were analyzed by thin-layer chromatography on a polyethyleneiminecellulose plate developed with $0.4 \mathrm{M}$ ammonium sulfate.

\section{ACKNOWLEDGMENTS}

We thank Dominique Lévesque for technical assistance. This work was funded by grants from the Canadian Institutes for Health Research and the Natural Sciences and Engineering Research Council of Canada to M.B., and a grant from the Rocky Mountain Regional Center for Excellence (U54 AI-065357) to B.J.G. M.B. is a Chercheur Boursier Junior 2 from the Fonds de recherche en santé du Québec and a member of the Infectious diseases group of the Centre de Recherche Clinique Étienne-Lebel.

Received February 19, 2009; accepted August 31, 2009.

\section{REFERENCES}

Ago H, Adachi T, Yoshida A, Yamamoto M, Habuka N, Yatsunami K, Miyano M. 1999. Crystal structure of the RNA-dependent RNA polymerase of hepatitis C virus. Structure 7: 1417-1426.

Ahola T, Kääriäinen L. 1995. Reaction in $\alpha$ virus mRNA capping: Formation of a covalent complex of nonstructural protein nsP1 with 7-methyl-GMP. Proc Natl Acad Sci 92: 507-511.

Assenberg R, Ren J, Verma A, Walter TS, Alderton D, Hurrelbrink RJ, Fuller SD, Bressanelli S, Owens RJ, Stuart DI, et al. 2007. Crystal structure of the Murray Valley encephalitis virus NS5 methyltransferase domain in complex with cap analogues. J Gen Virol 88: 2228-2236.

Benarroch D, Selisko B, Locatelli GA, Maga G, Romette JL, Canard B. 2004a. The RNA helicase, nucleotide 5 '-triphosphatase, and RNA $5^{\prime}$-triphosphatase activities of Dengue virus protein NS3 are $\mathrm{Mg}^{2+}$ dependent and require a functional Walker B motif in the helicase catalytic core. Virology 328: 208-218.

Benarroch D, Egolff MP, Mulard L, Guerreiri C, Romette JL, Canard B. 2004b. A structural basis for the inhibition of the
NS5 Dengue virus mRNA 2'-O-methyltransferase domain by ribavirin 5'-triphosphate. J Biol Chem 279: 35638-35643.

Benzaghou I, Bougie I, Picard-Jean F, Bisaillon M. 2006. Energetics of RNA binding by the West Nile virus RNA triphosphatase. FEBS Lett 580: 867-877.

Bisaillon M, Lemay G. 1997a. Characterization of the reovirus $\lambda 1$ protein RNA 5'-triphosphatase activity. J Biol Chem 272: 2995429957.

Bisaillon M, Lemay G. 1997b. Viral and cellular enzymes involved in synthesis of mRNA cap structure. Virology 236: 1-7.

Bollati M, Milani M, Mastrangelo E, Ricagno S, Tedeschi G, Nonnis S, Decroly E, Selisko B, Lamballerie X, Coutard B, et al. 2009. Recognition of the RNA cap in Wesselsbron virus NS5 methyltransferase domain: Implications for RNA capping mechanisms in flavivirus. J Mol Biol 385: 140-152.

Bougie I, Bisaillon M. 2004. The broad spectrum antiviral nucleoside ribavirin as a substrate for a viral RNA capping enzyme. J Biol Chem 279: 22124-22130.

Bougie I, Bisaillon M. 2009. Metal ion-binding studies highlight important differences between flaviviral RNA polymerases. Biochim Biophys Acta 1794: 50-60.

Bressanelli S, Tomei L, Roussel A, Incitti I, Vitale RL, Mathieu M, De Francesco R, Rey FA. 1999. Crystal structure of the RNA-dependent RNA polymerase of hepatitis C virus. Proc Natl Acad Sci 96: 13034-13039.

Brinton MA. 2002. The molecular biology of West Nile virus, a new invader of the western hemisphere. Annu Rev Microbiol 56: 371-402.

Choi KH, Groarke JM, Young DC, Kuhn RJ, Smith JL, Pevear DC, Rossmann MG. 2004. The structure of the RNA-dependent RNA polymerase from bovine viral diarrhea virus establishes the role of GTP in de novo initiation. Proc Natl Acad Sci 101: 4425-4430.

Cleveland DR, Zarbl H, Millward S. 1986. Reovirus guanylyltransferase is L2 gene product $\lambda 2$. J Virol 60: 307-311.

Cong P, Shuman S. 1993. Covalent catalysis in nucleotidyl transfer: A KTDG motif essential for enzyme-GMP complex formation by mRNA capping enzyme is conserved at the active sites of RNA and DNA ligases. J Biol Chem 268: 7256-7260.

Cong P, Shuman S. 1995. Mutational analysis of mRNA capping enzyme identifies amino acids involved in GTP binding, enzymeguanylate formation, and GMP transfer to RNA. Mol Cell Biol 15: 6222-6231.

Ding Q, Xiao L, Xiong S, Jia Y, Que H, Guo Y, Liu S. 2003. Unmatched masses in peptide mass fingerprints caused by crosscontamination: An updated statistical result. Proteomics 3: 13131317.

Doherty AJ, Hakansson K, Ho CK, Shuman S, Wigley DB. 1997. Crystallization of the RNA guanylyltransferase of Chlorella virus PBCV-1. Acta Crystallogr D Biol Crystallogr 53: 482-484.

Egloff MP, Benarroch D, Selisko B, Romette JL, Canard B. 2002. An RNA cap (nucleoside-2'-O)-methyltransferase in the flavivirus RNA polymerase NS5: Crystal structure and functional characterization. EMBO J 21: 2757-2768.

Egloff MP, Decroly E, Malet H, Selisko B, Benarroch D, Ferron F, Canard B. 2007. Structural and functional analysis of methylation and $5^{\prime}$-RNA sequence requirements of short capped RNAs by the methyltransferase domain of Dengue virus NS5. J Mol Biol 372: 723-736.

Fabrega C, Shen V, Shuman S, Lima CD. 2003. Structure of an mRNA capping enzyme bound to the phosphorylated carboxy-terminal domain of RNA polymerase II. Mol Cell 11: 1549-1561.

Furuichi Y, Shatkin AJ. 2000. Viral and cellular mRNA capping: Past and prospects. Adv Virus Res 55: 135-184.

Geiss BJ, Thompson AA, Andrews AJ, Sons RL, Gari HH, Keenan SM, Peersen OB. 2009. Analysis of flavivirus NS5 methyltransferase cap binding. J Mol Biol 385: 1643-1654.

Hakansson K, Wigley DB. 1998. Structure of a complex between a cap analogue and mRNA guanylyl transferase demonstrates the structural chemistry of RNA-capping. Proc Natl Acad Sci 95: 15051510 . 
Hakansson K, Doherty AJ, Shuman S, Wigley DB. 1997. X-ray crystallography reveals a large conformational change during guanylyl transfer by mRNA capping enzymes. Cell 89: 545-553.

Hausmann S, Ho CK, Schwer B, Shuman S. 2001. An essential function of Saccharomyces cerevisiae RNA triphosphatase Cet1 is to stabilize RNA guanylyltransferase Ceg1 against thermal inactivation. J Biol Chem 276: 36116-36124.

Heinz FX, Purcell MS, Gould EA, Howard CR, Houghton M, Moormann RJM, Rice CM, Thiel HJ. 2000. In Virus taxonomy, pp. 860-878. Academic, San Diego, CA.

Higman MA, Christen LA, Niles EG. 1994. The mRNA (guanine-7-) methyltransferase domain of the vaccinia virus mRNA capping enzyme: Expression in Escherichia coli and structural and kinetic comparison to the intact capping enzyme. J Biol Chem 269: 1497414981

Ho CK, Van Etten JL, Shuman S. 1996. Expression and characterization of an RNA capping enzyme encoded by Chlorella virus PBCV-1. $J$ Virol 70: 6658-6664.

Ho CK, Schwer B, Shuman S. 1998a. Genetic, physical, and functional interactions between the triphosphatase and guanylyltransferase components of the yeast mRNA capping apparatus. Mol Cell Biol 18: $5189-5198$.

Ho CK, Sriskanda V, McCraken S, Bentley D, Schwer B, Shuman S. 1998b. The guanylyltransferase domain of mammalian mRNA capping enzyme binds to the phosphorylated carboxy-terminal domain of RNA polymerase II. J Biol Chem 273: 9577-9585.

Ho CK, Lehman K, Shuman S. 1999. An essential surface motif (WAQKW) of yeast RNA triphosphatase mediates formation of the mRNA capping enzyme complex with RNA guanylyltransferase. Nucleic Acids Res 27: 4671-4678.

Hsiao J, Martinez-Costas J, Benavente J, Vakharia VN. 2002. Cloning, expression, and characterization of avian reovirus guanylyltransferase. Virology 296: 288-299.

Le Blois H, French T, Mertens PPC, Burroughs JN, Roy P. 1992. The expressed VP4 protein of bluetongue virus binds GTP and is the candidate guanylyltransferase of the virus. Virology 189: 757-761.

Lee JY, Chang C, Song HK, Moon J, Yang J, Kim HK, Kwon ST, Suh SW. 2000. Crystal structure of $\mathrm{NAD}^{+}$-dependent DNA ligase: Modular architecture and functional implications. EMBO $J$ 19: 1119-1129.

Lesburg CA, Cable MB, Ferrari E, Hong Z, Mannarino AF, Weber PC. 1999. Crystal structure of the RNA-dependent RNA polymerase from hepatitis $\mathrm{C}$ virus reveals a fully encircled active site. Nat Struct Biol 6: 937-943.

Liu M, Mattion NM, Estes MK. 1992. Rotavirus VP3 expressed in insect cells possesses guanylyltransferase activity. Virology 188: 77-84.

Liuzzi M, Mason SW, Cartier M, Lawetz C, McCollum RS, Dansereau N, Bolger G, Lapeyre N, Gaudette Y, Lagacé L, et al. 2005. Inhibitors of respiratory syncytial virus replication target cotranscriptional mRNA guanylylation by viral RNA-dependent RNA polymerase. J Virol 79: 13105-13115.

Luongo CL, Reinisch KM, Harrison SC, Nibert ML. 2000. Identification of the guanylyltransferase region and active site in reovirus mRNA capping protein $\lambda 2$. J Biol Chem 275: 2804-2810.

Malet H, Egloff MP, Selisko B, Butcher RE, Wright PJ, Roberts M, Gruez A, Sulzenbacher G, Vonrhein C, Bricogne G, et al. 2007. Crystal structure of the RNA polymerase domain of the West Nile virus nonstructural protein 5. J Biol Chem 282: 10678-10689.

Mao X, Shuman S. 1994. Intrinsic RNA (guanine-7) methyltransferase activity of the vaccinia virus capping enzyme D1 subunit is stimulated by the D12 subunit: Identification of amino acid residues in the D1 protein required for subunit association and methyl group transfer. J Biol Chem 269: 24472-24479.

Mao X, Schwer B, Shuman S. 1995. Yeast mRNA cap methyltransferase is a 50-kilodalton protein encoded by an essential gene. Mol Cell Biol 15: 4167-4174.

Mohd Jaafar F, Attoui H, Mertens PPC, de Micco P, de Lamballerie X. 2005. Structural organization of an encephalitic human isolate of
Banna virus (genus Seadornavirus, family Reoviridae). J Gen Virol 86: $1147-1157$

Nowak T, Farber PM, Wengler G, Wengler G. 1989. Analyses of the terminal sequences of West Nile virus structural proteins and of the in vitro translation of these proteins allow the proposal of a complete scheme of the proteolytic cleavages involved in their synthesis. Virology 169: 365-376.

Odell M, Sriskanda V, Shuman S, Nikolov DB. 2000. Crystal structure of eukaryotic DNA ligase illuminates the mechanism of nicksensing and strand-joining. Mol Cell 6: 1183-1193.

Oh JW, Ito T, Lai MMC. 1999. A recombinant hepatitis C virus RNAdependent RNA polymerase capable of copying the full-length viral RNA. J Virol 73: 7694-7702.

Pena L, Yanez J, Revilla Y, Vinuela E, Salas ML. 1993. African swine fever virus guanylyltransferase. Virology 193: 319-328.

Qiu T, Luongo CL. 2003. Identification of two histidines necessary for reovirus mRNA guanylyltransferase activity. Virology 316: 313324

Schnierle BS, Gershon PD, Moss B. 1992. Cap-specific mRNA (nucleoside-O2'-) methyltransferase and poly(A) polymerase stimulatory activities of vaccinia virus are mediated by a single protein. Proc Natl Acad Sci 89: 2897-2901.

Schwer B, Hausmann S, Schneider S, Shuman S. 2006. Poxvirus cap methyltransferase: Bypass of the requirement for the stimulatory subunit by mutations in the catalytic subunit and evidence for intersubunit allostery. J Biol Chem 281: 18953-18960.

Shatkin AJ. 1976. Capping of eukaryotic mRNAs. Cell 9: 645-653.

Shibagaki Y, Itoh N, Yamada Y, Hagata S, Mizumoto K. 1992. mRNA capping enzyme: Isolation and characterization of the gene encoding mRNA guanylyltransferase subunit from Saccharomyces cerevisiae. J Biol Chem 267: 9521-9528.

Shuman S. 1982. RNA capping by HeLa cell RNA guanylyltransferase. Characterization of a covalent protein-guanylate intermediate. $J$ Biol Chem 257: 7237-7245.

Shuman S. 2000. Structure, mechanism, and evolution of the mRNAcapping apparatus. Prog Nucleic Acid Res Mol Biol 66: 1-40.

Shuman S, Hurwitz J. 1981. Mechanism of mRNA capping by vaccinia virus guanylyltransferase: Characterization of an enzymeguanylate intermediate. Proc Natl Acad Sci 78: 187-191.

Supyani S, Hillman BI, Suzuki N. 2007. Baculovirus expression of the 11 mycoreovirus-1 genome segments and identification of the guanylyltransferase-encoding segment. J Gen Virol 88: 342-350.

Suzuki N, Kusano T, Matsuura Y, Omura T. 1996. Novel NTP binding property of rice dwarf phytoreovirus minor core protein P5. Virology 219: 471-474.

Vasiljeva L, Merits A, Auvinen P, Kääriäinen L. 2000. Identification of a novel function of the Alphavirus capping apparatus. RNA 5'-triphosphatase activity of Nsp2. J Biol Chem 275: 17281-17287.

Venkatesan S, Moss B. 1982. Eukaryotic mRNA capping enzymeguanylate covalent intermediate. Proc Natl Acad Sci 79: 340-344.

Wengler G, Czaya G, Farber PM, Hegemann JH. 1991. In vitro synthesis of West Nile virus proteins indicates that the aminoterminal segment of the NS3 protein contains the active centre of the protease which cleaves the viral polyprotein after multiple basic amino acids. J Gen Virol 72: 851-858.

Yap TL, Xu T, Chen YL, Malet H, Egloff MP, Canard B, Vasudevan SG, Lescar J. 2007. Crystal structure of the Dengue virus RNA-dependent RNA polymerase catalytic domain at 1.85- $\AA$ resolution. J Virol 81: 4753-4765.

Yon C, Teramoto T, Mueller N, Phelan J, Ganesh VK, Murthy KHM, Padmanabhan R. 2005. Modulation o the nucleoside triphosphate/ RNA helicase and 5'-RNA triphosphatase activities of Dengue virus type 2 nonstructural protein 3 (NS3) by interaction with NS5, the RNA-dependent RNA polymerase. J Biol Chem 280: 27412-27419.

Zhou Y, Ray D, Zhao Y, Dong H, Ren S, Li Z, Guo Y, Bernard KA, Shi PY, Li H. 2007. Structure and function of flavivirus NS5 methyltransferase. J Virol 1: 3891-3903. 

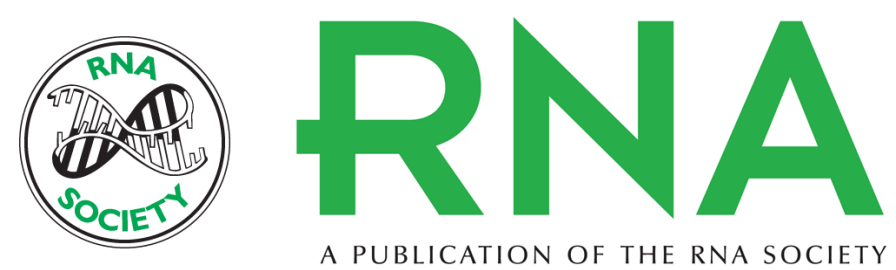

\section{The flavivirus NS5 protein is a true RNA guanylyltransferase that catalyzes a two-step reaction to form the RNA cap structure}

Moheshwarnath Issur, Brian J. Geiss, Isabelle Bougie, et al.

RNA 2009 15: 2340-2350 originally published online October 22, 2009

Access the most recent version at doi:10.1261/rna.1609709

References This article cites 63 articles, 32 of which can be accessed free at:

http://rnajournal.cshlp.org/content/15/12/2340.full.html\#ref-list-1

License

Email Alerting Receive free email alerts when new articles cite this article - sign up in the box at the Service top right corner of the article or click here.

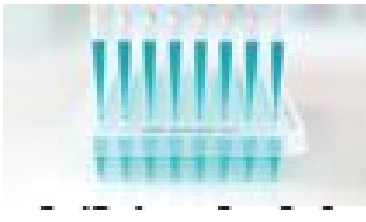

Providing Precise Solutions for your research.

To subscribe to RNA go to:

http://rnajournal.cshlp.org/subscriptions 